
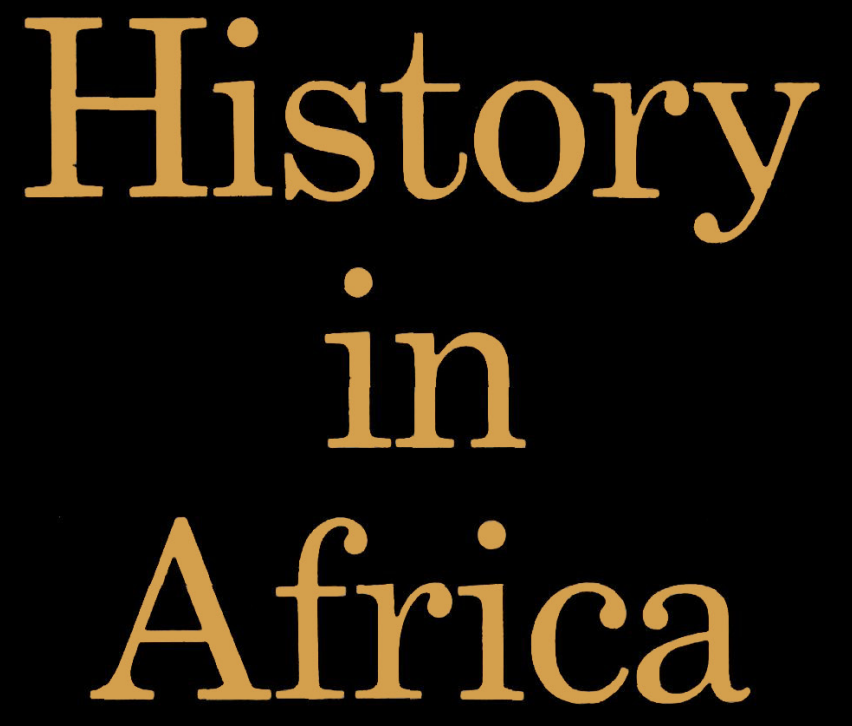

\title{
A JOURNAL OF METHOD
}

\section{David Henige, Editor}


HISTORY IN AFRICA

\section{Editorial Advisory Board}

A.E. Afigbo (University of Nigeria, Nsukka)

P.D. Curtin (Johns Hopkins University)

J.D. Fage (University of Birmingham)

S. Felerman (University of Wisconsin, Madison)

P.E.H. Halr (University of Liverpool)

D.H. Jones (University of London)

R.C.C. Law (University of Stirling)

J.C. Miller (University of Virginia)

A. Telxelra da Mota (Lisbon)

M. Twaddle (University of London)

A. van Dantzig (University of Ghana)

J. Vansina (University of Wisconsin, Madison)

History in Africa is published annually by the African Studies Association. Permission to reproduce materials from History in Africa should be obtalned from the African Studies Association. Subscriptions and other business correspondence should be sent to the African Studies Association, Epstein Building, Brandels University, Waltham, Massachusetts 02154. Manuscript and other editorial correspondence should be sent to David Hentge, Memorial Library, University of Wisconsin, Madison, Wisconsin 53706.

Articles in History in Africa represent neither the views of the African Studies Association nor those of its officers. The editor is responsible for the final selection of the content of History in Africa and reserves the right to reject any material deemed inappropriate for publication. Responsibility for opinions expressed and for the accuracy of facts published rests solely with the individual authors. Responsibility for the copyediting of the material is also the author's. 

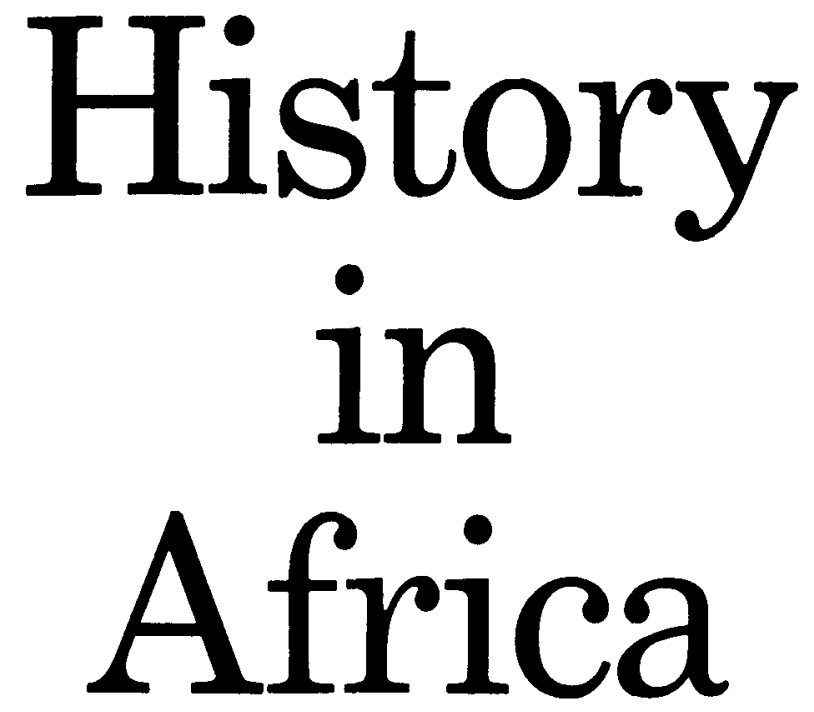

\title{
A JOURNAL OF METHOD
}

David Henige, Editor

\author{
AFRICAN STUDIES ASSOCIATION \\ Brandeis University \\ Waltham, Massachusetts 02154
}


Copyright 1977

\section{African Studies Association \\ All rights reserved}

No part of this publication may be reproduced or transmitted in any form or by any means, including photocopy, recording, or any information storage and retrieval system, without permission in writing from the publisher. Any author has the right to republish his article in whole or in part without requesting permission from the assoctation; others desiring permission to republish material should write the assoctation at the Epstein Building, Brandeis University, Waltham, Mass. 02154. Printed by Edwards Brothers, Inc., Ann Arbor, Michlgan, U.S.A. 
Chercher à connaitre n'est souvent qu'apprendre à douter

\section{Deshoulières}




\section{CONTENTS}

The Myth of Racial Strife and Merina Kinglists:

The Transformation of Texts

Gerald M. Berg

Volcanic Dust in the Atmosphere and the Interpretation of African Eclipse Traditions

Ronald W. Davis

History of Bantu Metallurgy: Some Linguistic Aspects

$P$. de Marat and F. Nsuka

Himba Epochs

Gordon D. Gibson

Impeachable Source? On the Use of the Second Edition of Reindorf's History as a Primary Source for the Study of Ghanaian History -- I

Ray Jenkins

Leselinyana la Lesotho and Sotho Historiography

Daniel $P$. Kunene

New Light on Venda Traditions: Mahumane's Account

of 1730

Gerhard Liesegang

Traditions of Genesis and the Luba Diaspora

Thomas $Q$. Reefe

Africana in the Indexes

Yvette Scheven

Traditional Myths and Linguistic Analysis: Singwaya Revisited

Thomas T. Spear

English Bosman and Dutch Bosman: A Comparison of Texts -- III

Albert van Dantzig

For Braudel: A Note on the "Ecole des Annales" and the Historiography of Africa

W.G. Clarence-Smith

Further Notes on Archival Research in Shaba Region, Zaire

Edgar Boyd 
The Congo/Zaire Archives of the Northern (Flemish)

Belgian Jesuit Province in Brussels, Belgium

willy De Craemer

Some Archives in the Bandundu and Equateur Regions of Zaire

Robert Harms

The Archives of the Congregation of the Immaculate Heart of Mary (C.I.C.M.)

Albert Raskin

Dross from Gold Coast Archives

Recently Published Articles: A Historical

Bibllography of Interest to Africanists

David Gardinier

Comparat1ve Bibliography 1977 


\section{ABBREVIATIONS}

IJAHS

$J A H$

THSG

International Journal of African Historical Studies

Joumaz of African History

Transactions of the Historical Society of Ghana 